\title{
UJI AKTIVITAS ANTIBAKTERI KOMBUCHA ROSELA (Hibiscus sabdariffa L.) TERHADAP BAKTERI Escherichia coli DAN Staphylococcus aureus
}

\author{
Adinda Ismu Chofidah ${ }^{1}$, M.Dwi Danu ${ }^{2}$, Iif H.Rosyidah ${ }^{3}$ \\ ${ }^{1,2}$ Program Studi S1 Farmasi Stikes Rumah Sakit Anwar Medika, Sidoarjo, Jawa Timur \\ ${ }^{3}$ Program Studi D3 Farmasi Stikes Rumah Sakit Anwar Medika, Sidoarjo, Jawa Timur \\ *Email:iifhanifanurrosyidah@gmail.com
}

\begin{abstract}
ABSTRAK: Rosela merupakan salah satu tanaman obat keluarga yang sering digunakan Sebagai obat tradisional untuk menghambat pertumbuhan bakteri. Rosela memiliki potensi untuk dijadikan minuman teh kombucha. Tujuan penelitian ini yaitu untuk mengetahui aktivitas antibakteri kombucha rosela (Hibiscus sabdariffa L) terhadap Escherichia coli dan Staphylococcus aureus. Kombucha rosela dibuat dengan cara memfermentasikan ekstrak rosela, starter dan gula selama 7 hari dengan variasi konsentrasi ekstrak 20, 30 dan 40 gram. Selanjutnya dilakukan uji aktivitas antibakteri dengan metode disk diffusion (tes Kirby \& Bauer) . Hasil uji aktivitas antibakteri menunjukkan bahwa kombucha rosela pada konsentrasi 20, 30 dan 40 gram dapat menghambat dan membunuh bakteri dengan baik, namun paling optimum menghambat bakteri adalah kombucha dengan konsentrasi rosela 40 gram menghasilkan zona hambat $6,5 \mathrm{~mm}$ terhadap bakteri E.coli yang dikategorikan dengan daya aktivitas antibakteri sedang. Sedangkan kombuca rosella memiliki daya hambat kurang dari $5 \mathrm{~mm}$ (daya hambat lemah) terhadap bakteri S.aureus.
\end{abstract}

Kata kunci : Kombucha, E.coli, S.aureus.

ABSTRACT: Roselle is a medicinal plant that is often used as a traditional medicine to inhibit bacterial growth. Roselle has the potential to be a kombucha tea drink. The purpose of this study was to study the antibacterial activity of kombucha rosela (Hibiscus sabdariffa L.) against Escherichia coli and Staphylococcus aureus. Kombucha roselle is made by fermenting roselle extract, starter and sugar for 7 days with variations in extract concentration of 20,30 and 40 grams. The antibacterial activity test was then performed using the disc diffusion method (Kirby \& Bauer test). Antibacterial activity test results showed kombucha rosella at concentrations of 20,30 and 40 grams can inhibit and fight bacteria well, but the most optimal inhibiting bacteria is kombucha with a 40 gram roselle concentration producing a $6.5 \mathrm{~mm}$ inhibition zone against E. coli bacteria categorized by medium antibacterial activity. While rosella kombuca has a inhibition of less than $5 \mathrm{~mm}$ (weak inhibition) against S. aureus bacteria.

Keywords : Kombucha, E.coli, S.aureus. 
Artikel Penelitian

\section{PENDAHULUAN}

Bakteri Escheichia coli dan Staphylococcus aureus merupakan flora normal dalam tubuh manusia, akan tetapi dapat bersifat patogen sehingga menyebabkan timbulnya berbagai peyakit infeksi (Parija, 2009).Escheichia coli dan Staphylococcus aureustelah banyak mengalami resisten terhadap antibiotik yang beredar dipasaran dapat menimbulkan permasalahan terapi pengobatan (Jawetz et al., 2001).

Beberapa hasil penelitian telah banyak menunjukkan bahwa tumbuhan yang memiliki aktivitas antibakteri sala satunya yaitu tanaman rosela. Rosela (Hibiscus sabdariffa L.) merupakan salah satu tanaman yang memiliki aktivitas antimikroba, antioksidan, anti-inflamasi, antidiabetes, antihipertensi dan antifungial (Nurnasari \& Khuluq, 2017). Antimikroba pada bunga rosela ditunjukkan oleh senyawa polifenol seperti flavonoid yaitu antosianin dan gosypetin, fenolik, tannin dan saponin (Estri \& Anggarbeni, 2015). Penelitian yang dilakukan sebelumnya oleh Jung et al., (2013) menunjukkan bahwa kandungan polifenol pada ekstrak bunga rosela dapat menghambat pertumbuhan bakteri Bacillus subtilis.

Salah satu pengolahan rosela adalah dapat dijadikan minuman kombucha rosela. Teh kombucha sendiri merupakan minuman hasil fermentasi larutan teh manis dengan memanfaatkan pertumbuhan simbiosis antara yeast (Saccharomyces cerevisiae, Saccharomyces ludwigii, Saccharomyces apiculatus varictas, Saccharomycespombe) dan bakteri (Acetobacter xylinum, gluconicum, Acetobacter ketogenum Pichia fermentas, Torula varietas), fermentasi dapat dilakukan selama 7-14 hari. Kombucha banyak dikonsumsi masyarakat sebagai minuman kesehatan karena memiliki banyak senyawa yang berkhasiat yaitu berbagai jenis asam (asam asetat, asam glukoronat, asam laktat, asam karbonat, asam folat, asam glukonat, asam condroitin sulfat dan asam hyaluronic), vitamin (B1, B2, B3, B6, B12, B15 dan C) serta polifenol yang memiliki efek antioksidan, antimikroba dan dapat mempengaruhi tubuh secara menyeluruh dengan menstabilkan metabolisme tubuh dan penawar racun (Naland, 2008).

Berdasarkan latar belakang tersebut, maka penelitian ini bertujuan untuk mengetahui aktivitas antibakteri kombucha rosela (Hibiscus sabdariffa L) terhadap Escherichia coli dan Staphylococcus aureusdengan metode disk diffusion (tes Kirby \& Bauer).

\section{METODE PENELITIAN}

Alat-alat yang digunakan yaitu alat gelas, sterilizing cupboard (Elitech/ZTP80 ECOh), shaker rotation (Health/H-MSR), inkubator (memmert), LAF (Lamnar Air Flow) (WINA:304) dan autoklaf (GEA/IS-B75L). 
Artikel Penelitian

Bahan-bahan yang digunakan yaitu starter kombucha (SNOBY), simplisia bungan rosella, gula, Nutrien Broth (NB), media Muller HintonAgar (MHA), bakteriEscherichia coli dan Bacillus subtilis.

\section{Prosedur Kerja Pembuatan Senyawa Uji Stater Kombucha}

Ditimbang kelopak bunga rosela sebanyak $50 \mathrm{~g}$, $60 \mathrm{~g}$ dan $70 \mathrm{~g}$, kemudian masukkan dalam $500 \mathrm{ml}$ air, direbus hingga mendidih, diamkan 10 menit dan disaring, kemudian tambahkan gula $10 \%$ dari volume total dan disterilkan pada suhu $121{ }^{0} \mathrm{C}$ selama 15 menit, tunggu larutan hingga dingin (suhu dibawah $50{ }^{0} \mathrm{C}$ ), ditambahkan $10 \%$ starter dari volume total. Setelah itu, erlenmeyer ditutup rapat dan dibungkus dengan kasa. Difermentasi selama 7 hari dalam kondisi gelap dan pada suhu ruang. Tiap tahapan dilakukan secara aseptis.

\section{Uji Aktivitas Antibakteri Dengan Metode disk diffusion}

Pada penelitian ini dilakukan dengan metode disk diffusion (tes Kirby \& Bauer) yang menggunakan suatu cakram kertas saring (paper disc) yang berfungsi sebagai tempat zat antimikroba. Kertas saring tersebut kemudian diletakkan pada lempeng agar yang telah diinokulasi mikroba uji, kemudiandiinkubasi pada waktu tertentu (1824 jam) dan suhutertentu $\left(37^{\circ} \mathrm{C}\right)$. Hasil pengamatan yang diperoleh berupa ada atau tidaknya daerah jernih yang terbentuk di sekelilig kertas cakram yang menunjukkan zona hambat pada pertumbuhan bakteri(Pleczar \& Chan, 2008).

Uji aktivitas antibakteri dilakukan dengan cara Muller HintonAgar (MHA) yang telah cair dituangkan kedalam 2 cawan perti steril dan dibiarkan membeku. Kemudian media agar dibagi dalam 3 wilayah untuk masing-masing konsentrasi kombucha rosela dengan cara memberi tanda pada bagian bawah cawan petri. Inokulasi bakteri Staphylococcus aureus dan Escherichia colidilakukan dengan dimasukkanswab kapas ke medium tabung reaksi yang berisi biakan bakteri ke dalam Muller HintonAgar (MHA) dan diratakan. Kemudian dicelupkan kertas cakram dan diletakkandiatas agar yang sudah membeku secara aseptik. Setelah itu inkubasi cawan petri pada suhu $36^{\circ} \mathrm{C}$ selama 24 jam. Zona hambat diukurdisekitar kertas cakram untuk tiap kontrol setelah diinkubasi selama 24 jam. Uji ini dilakukan sebanyak 5 kali replikasi.

\section{HASIL DAN PEMBAHASAN}

Pada tabel 1. Menunjukkan bahwa perbedaan konsentrasi memberikan pengaruh pada pengujian bakteri Staphylococcus aureus dan Escherichia coli

Rosela (Hibiscus sabdariffa L.) merupakan salah satu tanaman yang memiliki aktivitas antimikroba, antioksidan, anti-inflamasi, antidiabetes, antihipertensi dan antifungial (Nurnasari \& Khuluq, 2017). Antimikroba pada bunga rosela ditunjukkan oleh senyawa polifenol seperti flavonoid yaitu antosianin dan gosypetin, fenolik, tannin dan saponin (Estri \& Anggarbeni, 2015). Penelitian yang dilakukan sebelumnya oleh 


\section{Artikel Penelitian}

Jung et al., (2013) menunjukkan bahwa kandungan polifenol pada ekstrak bunga rosela dapat menghambat pertumbuhan bakteri Bacillus subtilis, Escherichia coli dan Staphylococcus aureus.

Tabel 1. Hasil Zona Hambat

\begin{tabular}{|c|c|c|c|}
\hline \multirow{2}{*}{ Nama Bakteri } & \multicolumn{3}{|c|}{$\begin{array}{c}\text { Luas Zona Hambat } \\
(\mathbf{m m})\end{array}$} \\
\cline { 2 - 4 } & $\mathbf{2 0} \mathbf{g}$ & $\mathbf{3 0} \mathbf{g}$ & $\mathbf{4 0} \mathbf{g}$ \\
\hline $\begin{array}{c}\text { Staphylococcus } \\
\text { aureus }\end{array}$ & $\mathbf{0} \mathbf{~ m m}$ & $\mathbf{1 , 5}$ & $\mathbf{5} \mathbf{~ m m}$ \\
$\mathbf{m m}$ & \\
\hline $\begin{array}{c}\text { Escherichia } \\
\text { coli }\end{array}$ & $\mathbf{0 ~} \mathbf{~ m m}$ & $\mathbf{1 , 8}$ & $\mathbf{6 , 5}$ \\
$\mathbf{m m}$ & $\mathbf{m m}$ \\
\hline
\end{tabular}

Penelitian sebelumnya juga dilakukan oleh Higginbotham et al., (2014) menunjukkan bahwa kandungan senyawa fenolik dan antosianin dapat membunuh bakteri Escherichia coli dan Staphylococcus aureus. Flavonoid mempunyai aktivitas sebagai antibakteri dengan cara mendenaturasi protein yang dapat menyebabkan aktivitas metabolisme sel bakteri berhenti. Saponin mempunyai aktivitas dengan cara menurunkan tegangan permukaan sel yang dapat menyebabkan bakteri tersebut lisis, senyawa tanin dapat mengkerutkan dinding sel (Estri \& Anggarbeni, 2015). Senyawa fenolik dalam tanaman dapat menyebabkan kerusakan pada membran sel bakteri (Teerarak et al., 2017)

Teh kombucha sendiri merupakan minuman hasil fermentasi larutan teh manis dengan memanfaatkan pertumbuhan simbiosis antara yeast dan bakteri yang mampu bertindak sebagai antibateri. Kandungan zat pada teh kombucha yang berperan sebagai anibakteri yaitu asam organik, khususnya asam asetat (Naland, 2008). Penelitian sebelumnya yang dilakukan oleh Al-Kalifawi (2014) menunjukkan bahwa kombucha teh hitam mampu menghambat pertumbuhan bakteri Escherichia coli, Pseudomonas aeruginosa dan Staphylococcus aureus.

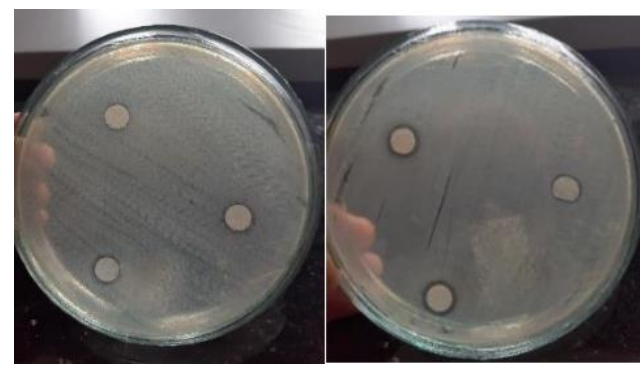
S. aureus
E. coli

\section{Gambar 1. Hasil Uji Kombucha Rosella (40 g) Sebagai Antibakteri}

Zona hambat yang terbentuk minimal, diduga karena lama fermentasi yang kurang dan konsentrasi simplisia rosela kurang, sehingga untuk penelitian selanjutnya perlu dilakukan uji perbandingan waktu lama fermentasi kombucha rosella terhadap aktivitas antibakterinya. 
Artikel Penelitian

\section{KESIMPULAN}

Berdasarkan hasil penelitian aktivitas antibakteri stater kombucha rosela baru memiliki memiliki daya hambat antibakteri pada konsentrasi $40 \%(\mathrm{~g} / \mathrm{v})$ yang ditandai dengan terbentuknya zona hambat terhadap bakteri Staphylococcus aureus dan Eschericia coli.

\section{DAFTAR PUSTAKA}

1. Al-Kalifawi, E. J. 2014. Antimicrobial Activity of Kombucha (KH) Tea against Bacteria Isolated From Diabetic Foot Ulcer. International Journal for Sciences and Technology, 9(1), 49-56. https://doi.org/10.12816/0010111

2. Estri, A. 2015. Uji Daya Hambat Air Rebusan Bunga Rosella (Hibiscus Sabdariffa L.) Terhadap Pertumbuhan Bakteri Esherichia Coli The Inhibition The Cooking Water Flower Rosella (Hibiscus Sabdariffa L.) On Esherichia Coli Bacteria Growth. Jurnal Wiyata, 2(1), 9-13.

3. Higginbotham, K. L., Burris, K. P., Zivanovic, S., Davidson, P. M., \& Stewart, C. N. 2014. Antimicrobial Activity of Hibiscus sabdariffa Aqueous Extracts against Escherichia coli O157: H7 and Staphylococcus aureus in a Microbiological Medium and Milk of Various Fat Concentrations. Journal of Food Protection, 77(2), 262-268. https://doi.org/10.4315/0362-028X.JFP-13-313

4. Jung, E., Kim, Y., \& Joo, N. 2013. Physicochemical properties and antimicrobial activity of Roselle (Hibiscus sabdariffa L.). Journal of the Science of Food and Agriculture, 93(15), 3769-3776. https://doi.org/10.1002/jsfa.6256

5. Naland, H. 2008. Kombucha Teh Dengan Seribu Khasiat. Jakarta: PT Agromedia Pustaka.

6. Nurnasari, E., \& Khuluq, A. D. (2018). Potensi Diversifikasi Rosela Herbal (Hibiscus sabdariffa L.) untuk Pangan dan Kesehatan. Buletin Tanaman Tembakau, Serat \& Minyak Industri, 9(2), 82. https://doi.org/10.21082/btsm.v9n2.2017.82-92

7. Pleczar dan Chan. 2008. Dasar-Dasar Mikrobiologi (Jilid 1). Jakarta: Universitas Indonesia Press.

8. Teerarak, M., Chamroon, L., Tangwatcharin, P., \& Pilasombut, K. 2017. Antioxidant and Antibacterial Activities against Food Pathogenic and Spoilage Bacteria by Hibicus Sabdariffa L. (Roselle) Extract. International Journal of Agricultural Technology, 13(3), 379-391. 